\title{
PLANT GROWTH-PROMOTING BACTERIA EFFECT IN WITHSTANDING DROUGHT IN WHEAT CULTIVARS
}

\author{
Efeito de bactérias promotoras de crescimento vegetal na resistência à seca em cultivares de trigo
}

Fernando Furlan; Kleber Saatkamp²; Camila Gazolla Volpiano ${ }^{3 *}$; Francisco de Assis Franco ${ }^{4}$; Marise Fonseca dos Santos $^{5}$; Eliane Cristina Gruszka Vendruscolo ${ }^{5}$; Vandeir Franscisco Guimarães ${ }^{6}$; Antonio Carlos Torres da Costa ${ }^{6}$

1 Master's degree in Agronomy; Department of Agronomy; Universidade Federal do Oeste do Paraná; 2 Chemical Engineering master's degree student; Department of Chemical Engineering; Universidade Federal do Oeste do Paraná; 3 Genetics and Molecular Biology master's degree student; Department of Genetics; Universidade Federal do Rio Grande do Sul, *gazollavolpiano@gmail.com;

4Wheat Improvement Manager; Cooperativa Central Agropecuária de Desenvolvimento Tecnológico e Econômico; 5Professor; Department of Biosciences; Universidade Federal do Paraná; 6Professor; Department of Agronomy; Universidade Federal do Oeste do Paraná;

Artigo enviado em 23/03/2017, aceito em 12/06/2017 e publicado em 07/07/2017.

Resumo - Este trabalho avaliou genótipos de trigo em condições de escassez de água inoculados com Aquospirillum brasilense e Herbaspirillum seropedicae, com e sem adubação nitrogenada. Para tanto, amostras para determinação do conteúdo relativo de água na folha (CRA) e do índice de estabilidade da membrana (IEM) foram coletadas no $1^{\circ}$ e $8^{\circ}$ dias de uma restrição total de água no estágio de emborrachamento. Além disso, os parâmetros de biomassa, nitrogênio total (NT) e produtividade foram determinados na colheita. Como resultado, os genótipos mostraram um desempenho distinto. Os dados de CRA e IEM revelaram que a inoculação de $A$. brasilense e $H$. seropedicae são capazes de conduzir o genótipo CD 120 à tolerância à seca. Além disso, o índice de grãos foi melhorado em todas as condições em que $H$. seropedicae estava presente em ambos os diferentes regimes de água. O H. seropedicae inoculado juntamente com adubo nitrogenado também aumentou o rendimento de grãos sob o regime de escassez de água. Além disso, A. brasilense inoculado com adubo nitrogenado foi capaz de melhorar a massa de 1000 grãos de plantas sob escassez de água. O cultivar Frontana exibiu a capacidade de manutenção do IEM e CRA apenas quando H. seropedicae ou ambas as bactérias mais adubo nitrogenado foram aplicados, no entanto, esta cultivar não apresentou diferenças em termos de massa fresca e seca da parte aérea e radicular, NT ou produtividade. Estes resultados apontaram H. seropedicae como promissora para inoculação em cereais e o CD120 como um bom modelo de planta para estudar a interação de plantas e bactérias.

Palavras-Chave - status hídrico, associação planta-bactéria, rizobactérias.

\begin{abstract}
This work evaluated wheat genotypes under water deficit inoculated with Azospirillum brasilense and Herbaspirillum seropedicae, with and without nitrogen fertilization. Samples of the plants were collected to evaluate its relative water content (RWC) and membrane stability index (MSI) at the $1^{\text {st }}$ and $8^{\text {th }}$ day of total water restriction at the booting stage. The plant biomass, total nitrogen $(\mathrm{TN})$ and grain yield were determined at harvesting. The genotypes showed different performances. According to the results of RWC and MSI, inoculation with A. brasilense and $H$. seropedicae can make the cultivar CD-120 more tolerant to drought. Grain index was improved with $H$. seropedicae in all conditions and water regimes. $H$. seropedicae with nitrogen fertilization increased grain yield under water deficit. $A$. brasilense with nitrogen fertilization improved the 1000-grain weight of plants under water deficit. The cultivar Frontana maintained its cellular integrity and RWC with nitrogen fertilization combined with $H$. seropedicae and with both bacteria, however the shoot and root fresh and dry weights, TN and yield of this cultivar showed no differences. These results show the inoculation with $H$. seropedicae as promising to cereals, and the cultivar CD-120 as a good plant model to study plant-bacteria interaction.
\end{abstract}

Keywords - water status, plant-microbe association, rhizobacteria 


\section{INTRODUCTION}

Wheat (Triticum aestivum L.) is one of the main products in the human daily diet (JONES, 2005), whose production reached more than 730 million $\mathrm{Mg}$ in 2017/2018 (FAO, 2017). The most limiting factor for wheat productivity is water deficit, which affects yield depending on its intensity and wheat phenological stage (OKUYAMA et al., 2004; ARAUS et al., 2008). In the Southern hemisphere, the wheat season coincides with a low precipitation period. Thus, $5 \%$ of the wheat production was lost in South Brazil in 2013 (GODINHO, 2013), contributing to decreasing the internal production supply to about half of the expected (CONAB, 2015).

Plants have developed adaptive physiological responses to cope with drought stress, such as reduction of transpiration by fast stomatal closure, decreasing of photosynthetic activity and deepening of roots (ALI et al., 2013; BECK et al., 2007). Plants with high antioxidant levels usually have greater tolerance to oxidative damages due to water stress (APEL; HIRT, 2004). Moreover, the synthesis of osmolytes can increase the osmotic potential inside cells in response to drought (FAROOQ et al., 2009). Importantly, all of these responses may vary among plant cultivars.

In order to maintain productivity, it is necessary to find efficient low-cost technologies to reduce drought effects over crops. The maintenance of crop yields under water restriction is the major challenge facing agriculture where plant growth-promoting bacteria (PGPB) can play an important role. In the last decades, many authors have been studying soil microorganisms as crops helpers in withstanding abiotic stresses (CHAKRABORTY et al., 2013). The PGPB have a potential to increase agricultural productivity through biological nitrogen fixation, promotion of greater absorption of nutrients by plant roots and reduction of deleterious effects of pathogens (BECKERS; CONRATH, 2007, FARINA et al., 2012, NAIMAN et al., 2009, ROJAS-TAPIAS et al., 2012, SPAEPEN et al., 2008). Remarkably, PGPB can also lead plants to drought tolerance by secreting compounds (including osmolytes) that increase root cells osmotic potential (DIMKPA et al., 2009).

Find efficient low-cost technologies to reduce effects of drought over crops is necessary to the maintenance of crop yields under water deficits, which is the major challenge faced by agriculture. Plant growthpromoting bacteria (PGPB) can be an important tool for this challenge. In the last decades, many authors have studied soil microorganisms to improve the tolerance of crops to abiotic stresses (CHAKRABORTY et al., 2013). PGPB have potential to increase agricultural productivity through biological nitrogen fixation, promotion of greater absorption of nutrients by plant roots and reduction of deleterious effects of pathogens (BECKERS; CONRATH, 2007, FARINA et al., 2012, NAIMAN et al., 2009, ROJAS-TAPIAS et al., 2012, SPAEPEN et al., 2008). Remarkably, PGPB can also promote tolerance to drought in plants by secreting compounds (including osmolytes) that increase osmotic potential of root cells (DIMKPA et al., 2009).

Herbaspirillum seropedicae (BALDANI et al., 1986) and Arospirillum brasilense (TARRAND et al., 1978) can colonize roots of cereals, and their efficiency to transfer fixed nitrogen to plants was already described in rice and sugarcane (BALDANI et al., 1997, BALDANI; BALDANI, 2005, BHATTACHARJEE et al., 2008, SENGUPTA; GUNRI, 2015). H. seropedicae in wheat crops can substitute nitrogen fertilization, according to a greenhouse experiment (NEIVERTH et al., 2014). Moreover, $A$. brasilense decreased grain yield loss in wheat under salt and drought stresses (CREUS et al., 1997; CREUS et al., 2004).

The beneficial effects of PGPB on plants depends on many factors, such as soil type, plant age, physiological stage and genotype, and the bacterial strain specificity (BALDANI; BALDANI, 2005, ROESCH et al., 2006, VARGAS et al., 2012). However, wheat genotypes have different capacities of association with bacteria. Root exudates act as chemical attractants for a vast number of heterogeneous, diverse and active metabolizing soil microbial communities (AHEMAD; KIBRET, 2014). These exudates differ according to the genotype, defining the microbiota around the roots (AIRA et al., 2010). These factors are essential to find solutions for specific potential application of these bacteria as bio-fertilizers.

Plants considered as models, showing a positive and negative plant-bacteria interaction, were described for cultivars of rice (IR42 and IAC 4440) (VARGAS et al., 2012), sugar cane (SP70 1143 and Chunee) (GOMES et al., 2005) and wheat (CD-120 and CD104) (NEIVERTH et al., 2014). However, few studies evaluated the performance of wheat model plants inoculated with PGPB and subjected to water deficit.

The cultivar CD-120 belongs to the Coodetec's wheat germplasm and has Mexican origin (CIMMYT) (VENDRUSCOLO et al., 2008). This genotype is described as resistant to the major diseases and of high grain yield potential and soft wheat quality (MARCHIORO et al., 2011). Frontana is an old, tall, redgrained cultivar with high level of seed dormancy and resistance to leaf rust and fusarium head blight (FHB) 
(ANDREOLI et al., 2006). This cultivar is an ancient genotype from which some Brazilian wheat varieties originated. It was included in the present study as control, since it probably underwent lower breeding pressure to respond to nitrogen fertilization and interactions with bacteria.

The objective of this study was to verify the performance of two wheat cultivars subjected to water deficit, under different inoculation with bacteria and fertilization conditions.

\section{MATERIAL AND METHODS}

The experiment was conducted at the Agricultural Research Central Cooperative COODETEC, Cascavel, State of Paraná, Brazil (24 $53^{\circ} 10.7^{\prime \prime S}$, 533' $\left.56.1^{\circ} \mathrm{W}\right)$, from May to September, 2012, using two wheat genotypes (CD-120 and Frontana).

The experiment was conducted in a complete randomized block design with five replications, consisted of two genotypes, eight different conditions (fertilizations and inoculations) and two water regimes (normal irrigation and water deficit). Results were subjected to analysis of variance (ANOVA) and compared by the Tukey's test at 5\% significance level using the program GENES (CRUZ, 2013).

Six seeds were sown per pot, which contained approximately $4.5 \mathrm{~kg}$ of 5 -mm sieved, not-autoclaved Red Latosol that were locally collected, arranged in a greenhouse to have the same solar radiation, temperature $\left(25 \pm 2^{\circ} \mathrm{C}\right)$ and relative humidity $(60 \%)$. No chemical fertilizers were applied due to the good soil characteristics $(\mathrm{pH}=6.40, \mathrm{P}=60.00 \mathrm{mg}$ $\mathrm{dm}^{-3}, \mathrm{~K}=1.14 \mathrm{cmol} \mathrm{dm}^{-3}, \mathrm{Ca}=6.69 \mathrm{cmol} \mathrm{dm}^{-3}, \mathrm{Mg}=3.03$ $\mathrm{cmol} \mathrm{dm}^{-3}, \mathrm{H}+\mathrm{Al}=3.18 \mathrm{cmol} \mathrm{dm}^{-3}, \mathrm{Cu}=14.45 \mathrm{mg} \mathrm{dm}^{-3}, \mathrm{Mn}$ $=400.00 \mathrm{mg} \mathrm{dm}^{-3}, \mathrm{Fe}=21.00 \mathrm{mg} \mathrm{dm}^{-3}, \mathrm{Zn}=32.49 \mathrm{mg} \mathrm{dm}^{-3}$, $\mathrm{BS}=10.86 \mathrm{cmol} \mathrm{dm}^{-3}$ and organic matter $\left.=41.6 \mathrm{~g} \mathrm{dm}^{-3}\right)$.

The pre-inoculum (of both H. seropedicae SMR1 and $A$. brasilense ABV5 strains) were prepared from a single colony in $5 \mathrm{~mL}$ of liquid DYGS medium maintained at $28{ }^{\circ} \mathrm{C}$ in a shaker (120 rpm overnight). One $\mathrm{mL}$ of the pre-inoculum was transferred to a $20-\mathrm{mL}$ conic tube containing the liquid DYGS medium originating the inoculum. The inocula grew until the log phase (OD $660 \mathrm{~nm}$ ) and the seed inoculation was performed before sowing, in order to provide $10^{6}$ cells seed $^{-1}$ for $H$. seropedicae and $10^{7}$ cells seed $^{-1}$ for $A$. brasilense (JUHNKE et al., 1989; SANTOS et al., 2010).

The treatments consisted of control (C1), inoculation with $H$. seropedicae (C2), inoculation with $A$. brasilense (C3), inoculation with $H$. seropedicae and $A$. brasilense (C4), nitrogen fertilization (C5), inoculation with
H. seropedicae and nitrogen fertilization (C6), inoculation with $A$. brasilense and nitrogen fertilization (C7), inoculation with $H$. seropedicae and $A$. brasilense and nitrogen fertilization (C8).

Thinning was performed 30 days after planting, keeping four plants in each pot, followed by nitrogen fertilization (142 kg urea ha-1). The plants were subjected to two water regimes, plants with normal irrigation (once a day) (1) and plants under total water restriction for 8 days in the early booting stage, from the $65^{\text {th }}$ for the cultivar CD-120 and from the $75^{\text {th }}$ day after germination for the cultivar Frontana (2) (Zadoks 4.5) (ZADOKS et al., 1974). After this period, plants from both water regimes were irrigated normally until harvesting. Leaf samples were collected from plants at the same time in both water regimes, in the $1^{\text {st }}$ and $8^{\text {th }}$ day after water restriction. Samples were used to quantify the relative water content (RWC), following the protocol proposed by Schonfeld et al. (1988), and membrane stability index (MSI), according to Chandra Babu et al. (2004). Harvests were performed at 139 (Frontana) and 120 (CD-120) days after germination, and the plants were evaluated according to production parameters, including plant fresh and dry weights, shoot total nitrogen (TN), grain weight per plant (grain yield) and 1000-grain weight (grain index) (BREMNER; MULVANEY, 1982).

\section{RESULTS AND DISCUSSION}

\section{Relative water content and membrane stability index}

RWC and MSI were used to assess the water status and membrane stability of plants subjected to water deficit and inoculation with $A$. brasilense and/or $H$. seropedicae and/or nitrogen fertilization. RWC and MSI data showed that the inoculation with $A$. brasilense and $H$. seropedicae promoted tolerance to drought for the cultivar CD-120. The same trend was observed for the cultivar Frontana, but at a lesser extent. The cultivar CD-120 maintained a high RWC until the $8^{\text {th }}$ day of water restriction, under all inoculation conditions (Figure 1A).

The lowest RWC were found in the control (C1) $(12 \%)$ and nitrogen fertilization (C5) (41\%) of the cultivar CD-120. These results represent a decrease in RWC of 84 and $51 \%$, respectively, compared with control plants, denoting the effect of water deficit in the plants. The RWC of plants of the cultivar Frontana under irrigation and water stress, with $A$. brasilense (C2) or $H$. seropedicae (C3) and with nitrogen plus the bacteria strains (C8) was similar (Figure 1B). 

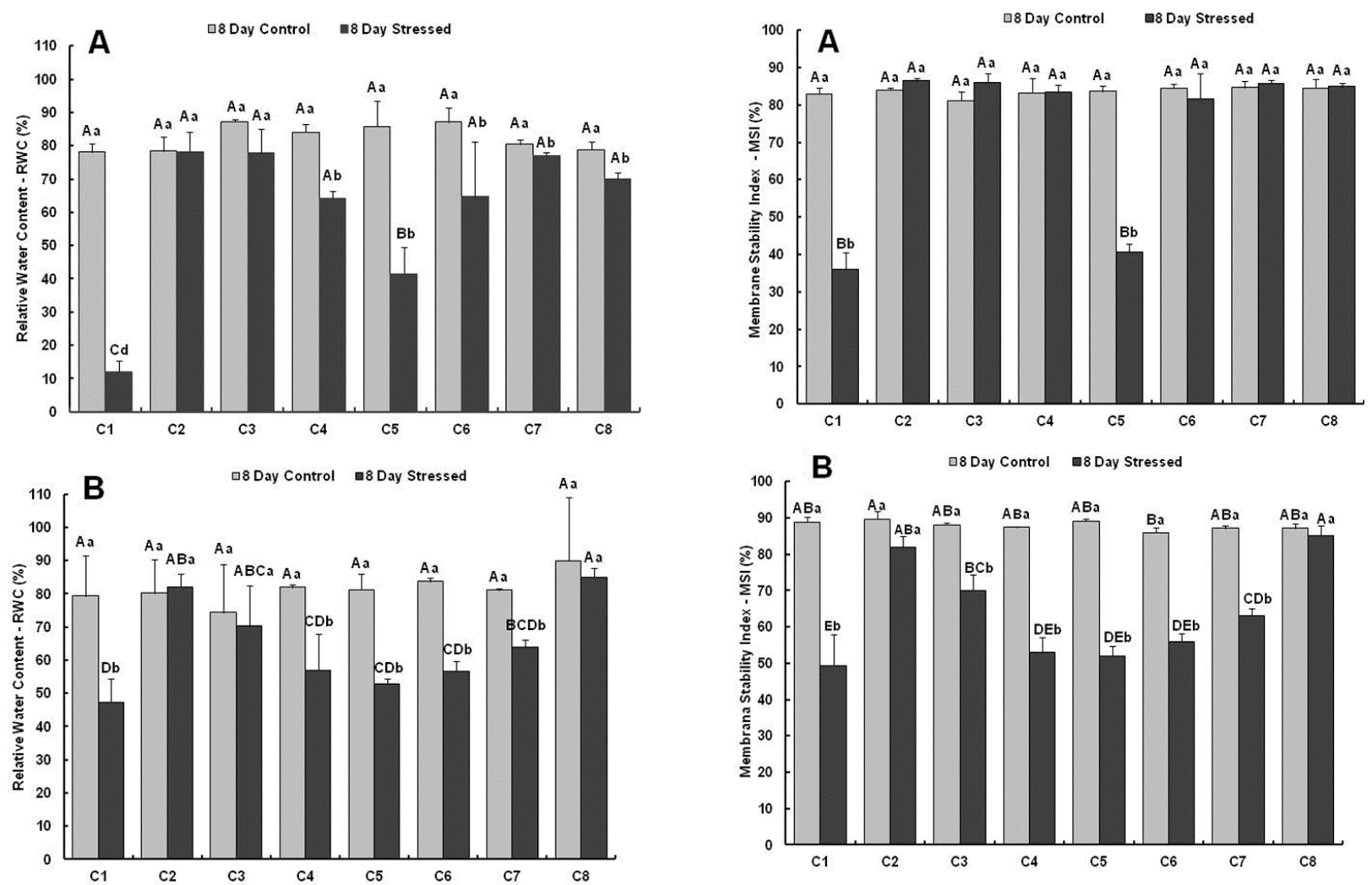

Figure 1 - Relative Water Content of A) CD 120 B) Frontana at irrigated and stressed conditions. C1 control; C2 - inoculation with $H$. seropedicae; C3 inoculation with $A$. brasilense; C4 - inoculation with $H$. seropedicae and $A$. brasilense; C5 - nitrogen fertilization; C6 - inoculation with $H$. seropedicae and nitrogen fertilization; C7 - inoculation with $A$. brasilense and nitrogen fertilization; $\mathrm{C} 8$ - inoculation with $\boldsymbol{H}$. seropedicae and $\boldsymbol{A}$. brasilense and nitrogen fertilization. Means followed by the same capital letter in the column (corresponds to different water regime - irrigated and stressed) and small letter on the column (corresponds to differences among fertilization/inoculation conditions) did not differ statistically by the Tukey Test $(p<5 \%)$.

The MSI data of CD-120 clearly showed its maintenance of cellular membrane in most conditions, excepted control (C1) and nitrogen fertilization (C5), which had decreases in membrane integrity of $54 \%$ and $48 \%$, respectively (Figure $2 \mathrm{~A}$ ).

The MSI of the cultivar Frontana showed the same trend of the RWC (Figure 2B). The data indicated a better membrane protection when inoculated with $H$. seropedicae (C2) and with both strains plus nitrogen fertilization (C8).

Figure 2 - Membrane Stability Index of A) CD 120 B) Frontana at irrigated and stressed conditions. C1 control; C2 - inoculation with $H$. seropedicae; C3 inoculation with $A$. brasilense; $\mathrm{C} 4$ - inoculation with $H$. seropedicae and $\boldsymbol{A}$. brasilense; C5 - nitrogen fertilization; C6 - inoculation with $H$. seropedicae and nitrogen fertilization; C7 - inoculation with $A$. brasilense and nitrogen fertilization; $\mathrm{C} 8$ - inoculation with $\boldsymbol{H}$. seropedicae and $\boldsymbol{A}$. brasilense and nitrogen fertilization. Means followed by the same capital letter in the column (corresponds to different water regime - irrigated and stressed) and small letter on the column (corresponds to differences among fertilization/inoculation conditions) did not differ statistically by the Tukey Test $(\mathrm{p}<5 \%)$.

The RWC and MSI of plants under water deficit were similar to those reported by Lemos et al. (2011) for another COODETEC genotype under the same water regimes. These authors found significant decreases in RWC (31\%) and MSI (15\%) in plants under water deficit, compared with those under normal irrigation.

The low RWC and MSI found are indicators of severe membrane injuries, which compromised the cell recovery after the drought period. Reduction in electrolyte losses under water stress results in a better membrane integrity and tolerance to oxidative stress (LIU et al., 2011). 
Inoculation with $A$. brasilense induced homeostatic mechanisms that generate tolerance to drought in prime wheat (KASIM et al., 2013). Moreover, drought increases reactive oxygen species production (BECK et al., 2007), which can damage cells and activate defense responses to water stress (DOORNBOS et al., 2012; FAROOQ et al., 2009). The MSI of inoculated plants of the cultivar CD-120 indicated a protection against oxidative damage using the bacteria as a biopriming (BECKERS et al., 2007, COMPANT et al., 2005, ZAMIOUDIS; PIETERSE, 2012; MASWADA; EL-KADER, 2016). However, the treatment with nitrogen fertilization (C5) did not prevent damage to the membrane structure and loss of turgor in both genotypes subjected to water deficit.

\section{Fresh and dry weight and yield parameters}

Booting seems to be the most critical phenological stage for wheat subjected to water deficit (LEMOS et al., 2011; KHAN et al., 2015). High shoot fresh weight and TN indicate a plant growth with a normal metabolism. Drought affected the shoot weight and TN of both genotypes (Table 1), showing that water is essential to the physiological apparatus.

$H$. seropedicae (C2) increased the fresh and dry shoot weight of CD-120 under irrigation (Table 1). However, under water deficit, this cultivar showed increments in fresh shoot weight with nitrogen fertilization plus inoculation with $H$. seropedicae (C6) and $H$. seropedicae and $A$. brasilense (C8) with 1.8-fold and 2fold respectively, compared with the control. The highest shoot dry weight $(17 \%)$ and $\mathrm{TN}(35 \%)$ content was found in the treatment with both bacteria and $\mathrm{N}$ fertilization (C8) in plants under water stress.

Grain weight per plant and 1000-grain weight was improved in all conditions with $H$. seropedicae (C2) under normal water regime. Moreover, H. seropedicae with nitrogen fertilization (C6) improved grain weight per plant of the cultivar CD-120 under water deficit. The good productive performance and higher RWC and MSI of the cultivar CD-120 indicated a beneficial interaction with $H$. seropedicae, thus, this cultivar can be considered as a positive model (NEIVERTH et al., 2014) to evaluate plant-bacteria interaction in water stress conditions.

Furthermore, CD-120 showed increases in grain yield (8-fold) and 1000-grain weight (1.3-fold) with nitrogen fertilization plus inoculation with $H$. seropedicae
(C6) and $A$. brasilense (C7) (Table 2). Its higher yields can be explained by a delayed water loss due to the presence of bacteria, involving several morphophysiological and biochemical changes, such as rises in abcisic acid (ABA), lipid peroxidation and proline (COHEN et al., 2015).

Although the results showed good responses of the cultivar CD-120, there are few works in the literature comparing its performances. However, Alamri and Mostafa (2009) evaluated the effect of $\mathrm{N}$ supply and inoculation with $A$. brasilense in wheat subjected to a saline condition ( $8 \%$ ) and found an increase of $9 \%$ in 1000 -grain weight without $\mathrm{N}$ fertilization and of $21 \%$ when $\mathrm{N}$ was applied. In the present work, the application of nitrogen fertilization (C5) did not increase grain yield and grain index of plants under water standard regime.

The cultivar Frontana has usually high shoot weight phenotype, which explains its highest fresh and dry shoot weight and TN (Table 1). The parameters of this cultivar did not differ significantly with the inoculations or water regimes (Tables 1 and 2). The Frontana shoot dry weight of plants inoculated with $A$. brasilense increased in approximately 2 -fold with nitrogen fertilization (C7) under water deficit condition. Nevertheless, TN content decreased under the same condition. The grain weight per plant under water deficit of the cultivar Frontana, inoculated with $A$. brasilense and $H$. seropedicae (C2, C3 and C4) was also improved. $H$. seropediace plus nitrogen fertilization (C7) promoted the highest grain weight per plant, but the 1000 -grain weight did not increase (Table 2).

Rhizobacteria-induced drought endurance and resilience (RIDER) that includes changes in the levels of phytohormones, defense-related proteins and enzymes, antioxidants and epoxypolysaccharide have been observed for microbe-mediated plant responses (MEENA et al., 2017). According to the results of the present work, $A$. brasilense and $H$. seropedicae can be considered as RIDERs, since they improved the plants of both genotypes.

The cultivar CD-120 (commercial cultivar) seems to interact better with bacteria, minimizing the drought stress effects than the cultivar Frontana (ancestral cultivar). Probably, CD-120 presents a better anti-oxidative enzymatic profile and the presence of bacteria can optimize it, conferring a better tolerance to drought stress to this cultivar (HANDIA et al., 2004; HAYAT et al., 2010). 
Table 1 - Effect of different conditions of fertilization and/or inoculation with $H$. seropedicae and $A$. brasilense on biomass parameters of wheat varieties submitted to different water regimes.

\begin{tabular}{|c|c|c|c|c|c|c|c|c|c|c|c|c|}
\hline \multicolumn{13}{|c|}{ WATER STANDARD REGIME } \\
\hline & \multicolumn{4}{|c|}{ Fresh Shoot Mass (g) } & \multicolumn{4}{|c|}{ Shoot Dry Mass(g) } & \multicolumn{4}{|c|}{$\begin{array}{c}\text { Shoot Total Nitrogen Content } \\
\left(\mathrm{g} \cdot \mathrm{kg}^{-1}\right)\end{array}$} \\
\hline & \multicolumn{2}{|c|}{ CD 120} & \multicolumn{2}{|c|}{ Frontana } & \multicolumn{2}{|c|}{ CD 120} & \multicolumn{2}{|c|}{ Frontana } & \multicolumn{2}{|c|}{ CD 120} & \multicolumn{2}{|c|}{ Frontana } \\
\hline C1 & 10.1 & $\mathrm{Bb}^{*}$ & 22.2 & $\mathrm{Aa}^{*}$ & 7.7 & $\mathrm{Bb}^{*}$ & 15.2 & $\mathrm{Aa}^{*}$ & 1.4 & $\mathrm{Aab}$ & 1.9 & $\mathrm{Aa}$ \\
\hline C2 & 21.5 & $\mathrm{Aa}^{*}$ & 22.3 & $\mathrm{Aa}^{*}$ & 14.6 & $\mathrm{Aa}^{*}$ & 14.1 & $\mathrm{Aa}$ & 1.4 & Bab & 2.3 & $\mathrm{Aa}$ \\
\hline C3 & 7.7 & $\mathrm{Bb}$ & 17.6 & $\mathrm{Aa}$ & 6.3 & $\mathrm{Bb}^{*}$ & 11.9 & $\mathrm{Aa}$ & 1.9 & $\mathrm{Ba}$ & 2.4 & $\mathrm{Aa}^{*}$ \\
\hline C4 & 11.3 & Bb* & 19.1 & $\mathrm{Aa}$ & 9.2 & $\mathrm{Bb}^{*}$ & 13.3 & $\mathrm{Aa}$ & 1.7 & Aab & 2.0 & $\mathrm{Aa}$ \\
\hline C5 & 7.9 & $\mathrm{Bb}^{*}$ & 13.2 & $\mathrm{Aa}$ & 6.2 & $\mathrm{Ab}$ & 8.3 & $\mathrm{Aa}$ & 1.3 & $\mathrm{Bab}$ & 2.5 & $\mathrm{Aa}^{*}$ \\
\hline C6 & 5.8 & $\mathrm{Bb}$ & 18.2 & $\mathrm{Aa}$ & 4.4 & $\mathrm{Bb}$ & 13.6 & $\mathrm{Aa}^{*}$ & 1.7 & $\mathrm{Bab}$ & 2.7 & $\mathrm{Aa}^{*}$ \\
\hline C7 & 7.3 & $\mathrm{Ab}$ & 13.1 & $\mathrm{Aa}$ & 5.7 & $\mathrm{Ab}$ & 9.5 & $\mathrm{Aa}$ & 1.5 & $\mathrm{Bab}$ & 2.8 & $\mathrm{Aa}^{*}$ \\
\hline $\mathrm{C} 8$ & 10.3 & $\mathrm{Bb}$ & 18.2 & $\mathrm{Aa}^{*}$ & 7.7 & $\mathrm{Bb}$ & 13.6 & $\mathrm{Aa}^{*}$ & 1.1 & $\mathrm{Bb}$ & 2.5 & $\mathrm{Aa}$ \\
\hline \multicolumn{13}{|c|}{ WATER SHORTAGE REGIME } \\
\hline & \multicolumn{4}{|c|}{ Fresh Shoot Mass (g) } & \multicolumn{4}{|c|}{ Shoot Dry Mass(g) } & \multicolumn{4}{|c|}{$\begin{array}{c}\text { Shoot Total Nitrogen Content } \\
\left(\mathrm{g} \cdot \mathrm{kg}^{-1}\right)\end{array}$} \\
\hline & \multicolumn{2}{|c|}{ CD 120} & \multicolumn{2}{|c|}{ Frontana } & \multicolumn{2}{|c|}{ CD 120} & \multicolumn{2}{|c|}{ Frontana } & \multicolumn{2}{|c|}{ CD 120} & \multicolumn{2}{|c|}{ Frontana } \\
\hline C1 & 5.1 & Bab & 11.3 & $\mathrm{Aa}$ & 4.4 & Aab & 6.0 & $\mathrm{Ab}$ & 2.0 & Aab & 1.2 & $\mathrm{Bab}$ \\
\hline C2 & 5.3 & $\mathrm{Bab}$ & 12.1 & $\mathrm{Aa}$ & 3.9 & $\mathrm{Bb}$ & 6.3 & $\mathrm{Aab}$ & 1.9 & Aab* & 1.9 & $\mathrm{Aa}$ \\
\hline C3 & 5.7 & $\mathrm{Bab}$ & 14.2 & $\mathrm{Aa}$ & 4.4 & $\mathrm{Bab}$ & 9.8 & $\mathrm{Aab}$ & 1.8 & $\mathrm{Ab}$ & 1.6 & $\mathrm{Aab}$ \\
\hline C4 & 5.2 & $\mathrm{Bab}$ & 15.3 & $\mathrm{Aa}$ & 4.3 & $\mathrm{Bab}$ & 10.6 & Aab & 2.5 & $\mathrm{Aab}^{*}$ & 1.7 & $\mathrm{Bab}$ \\
\hline C5 & 4.2 & $\mathrm{Bb}$ & 11.7 & $\mathrm{Aa}$ & 4.0 & $\mathrm{Bab}$ & 7.9 & Aab & 2.3 & $\mathrm{Aab}^{*}$ & 2.1 & $\mathrm{Aa}$ \\
\hline C6 & 9.6 & Aab* & 10.2 & $\mathrm{Aa}$ & 5.3 & $\mathrm{Bab}$ & 7.5 & Aab & 1.9 & $\mathrm{Ab}$ & 1.9 & $\mathrm{Aa}$ \\
\hline C7 & 8.8 & Bab & 17.7 & $\mathrm{Aa}$ & 5.1 & $\mathrm{Bab}$ & 12.5 & $\mathrm{Aa}$ & 2.4 & Aab* & 0.7 & $\mathrm{Bb}$ \\
\hline $\mathrm{C} 8$ & 10.3 & $\mathrm{Aa}$ & 10.2 & $\mathrm{Aa}$ & 6.0 & $\mathrm{Aa}$ & 7.5 & Aab & 2.7 & $\mathrm{Aa}^{*}$ & 1.8 & $\mathrm{Ba}$ \\
\hline
\end{tabular}

Table 2 - Effect of different conditions of fertilization and/or inoculation with $H$. seropedicae and $A$. brasilense on yield parameters of wheat varieties submitted to different regimes of water support.

\begin{tabular}{|c|c|c|c|c|c|c|c|c|}
\hline \multicolumn{9}{|c|}{ WATER STANDARD REGIME } \\
\hline & \multicolumn{4}{|c|}{ Grain Mass/plant (g) } & \multicolumn{4}{|c|}{ 1000-Grain Mass (g) } \\
\hline & \multicolumn{2}{|c|}{ CD 120} & \multicolumn{2}{|c|}{ Frontana } & \multicolumn{2}{|c|}{ CD 120} & \multicolumn{2}{|c|}{ Frontana } \\
\hline C1 & 2.8 & Abc* & 2.4 & Aab* & 3.4 & Ad* & 3.1 & $\mathrm{Ba}$ \\
\hline $\mathrm{C} 2$ & 6.9 & $\mathrm{Aa}^{*}$ & 3.1 & $\mathrm{Ba}^{*}$ & 3.8 & Aabc* & 3.1 & $\mathrm{Ba}$ \\
\hline C3 & 2.8 & Abc* & 2.4 & Aab* & 3.6 & 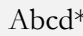 & 3.0 & $\mathrm{Ba}$ \\
\hline $\mathrm{C} 4$ & 3.7 & $\mathrm{Ab}^{*}$ & 2.4 & $\mathrm{Aab}$ & 4.0 & $\mathrm{Aa}^{*}$ & 2.8 & Bab \\
\hline C5 & 1.7 & Ac* & 0.6 & Ac & 3.5 & Acd* & 2.5 & $\mathrm{Bb}$ \\
\hline C6 & 2.6 & Abc* & 2.0 & Aab* & 3.9 & Aab & 2.5 & $\mathrm{Bb}$ \\
\hline $\mathrm{C} 7$ & 2.0 & $\mathrm{Ac}^{*}$ & 1.7 & Abc & 3.5 & Acd & 2.6 & Bab \\
\hline $\mathrm{C} 8$ & 3.0 & Abc* & 2.0 & Bab* & 3.7 & Aabc* & 2.7 & Bab* \\
\hline \multicolumn{9}{|c|}{ WATER SHORTAGE REGIME } \\
\hline & \multicolumn{4}{|c|}{ Grain Mass/plant (g) } & \multicolumn{4}{|c|}{ 1000-Grain Mass (g) } \\
\hline & \multicolumn{2}{|c|}{ CD 120} & \multicolumn{2}{|c|}{ Frontana } & \multicolumn{2}{|c|}{ CD 120} & \multicolumn{2}{|c|}{ Frontana } \\
\hline C1 & 0.2 & $\mathrm{Ab}$ & 0.2 & $\mathrm{Ad}$ & 2.9 & Ad & 3.1 & Aab \\
\hline C2 & 0.6 & $\mathrm{Bb}$ & 1.5 & Aab & 3.3 & Aabc & 3.5 & $\mathrm{Aa}$ \\
\hline C3 & 0.9 & Aab & 1.5 & Aab & 3.1 & Acd & 3.3 & Aab \\
\hline C4 & 0.3 & $\mathrm{Bb}$ & 1.5 & Aab & 3.3 & Ac & 2.8 & Bbcd \\
\hline C5 & 0.4 & $\mathrm{Ab}$ & 0.4 & Acd & 3.2 & Acd & 2.7 & Bbcd \\
\hline C6 & 1.6 & $\mathrm{Aa}$ & 1.1 & $\mathrm{Abc}$ & 3.7 & $\mathrm{Aa}$ & 2.5 & Bcd \\
\hline C7 & 0.7 & $\mathrm{Bb}$ & 1.9 & $\mathrm{Aa}$ & 3.7 & $\mathrm{Aa}$ & 2.9 & Babc \\
\hline C8 & 0.7 & $\mathrm{Ab}$ & 0.2 & Bcd & 3.3 & $A b c$ & 2.2 & $\mathrm{Bd}$ \\
\hline
\end{tabular}

For both tables means followed by the same capital letter in the line (correspond to genotypes - CD120 and Frontana) and small letter on the column (correspond to different conditions of fertilization and/or inoculation) did not differ statistically by the Tukey test $(\mathrm{p}<0.05)$. Means of water regimes followed by $*$ are statistically different by Tukey test 
Comparing CD120 (commercial cultivar) and Frontana (ancestral cultivar), the former seems to interact better to the presence of bacteria minimizing the drought stress effects. Probably, CD 120 presents a better anti-oxidative enzymatic profile and the presence of bacteria could optimize it conferring better tolerance to drought stress (HANDIA et al., 2004; HAYAT et al.,2010)

\section{CONCLUSION}

The cultivar CD-120 can be used as a plant model in studies evaluating the effect of plant growthpromoting bacteria on tolerance to drought and yield performance in wheat.

\section{ACKNOWLEDGEMENTS}

The authors thank the Agricultural Research Central Cooperative (COODETEC) for supporting this research by providing the seeds, infrastructure and assisting in the soil analysis.

\section{REFERENCES}

AHEMAD, M.; KIBRET, M. Mechanisms and applications of plant growth promoting rhizobacteria: Current perspective. Journal of King Saud University Science, v.26: p.1-20, 2014.

AIRA M, GÓMEZ-BRANDÓN M, LAZCANO C, BAATH E, DOMÍNGUEZ J. Plant genotype strongly modifies the structure and growth of maize rhizosphere microbial communities. Soil Biology and Biochemistry, v.42,p.2276-2281.2010.

ALAMRI SA, MOSTAFA YS. Effect of nitrogen supply and Azospirillum brasilense Sp-248 on the response of wheat to seawater irrigation. Saudi Journal of Biological Sciences. v16; n.2; p.101-107.2009.

ALI, A.; ALI N.; ULLAH, N.; ULLAH, F.; ADNAN M.; AHMED Z. S. Effect of drought stress on the physiology and yield of the Pakistani wheat germplasms. International Journal of Advancements in Research \& Technology, v. 2, n. 7, p. 419-430, 2013.

ANDREOLI, A.; BASSOI, MC; BRUNETTA, D. Genetic control of seed dormancy and pre-harvest sprouting in wheat. Scientia Agricola v.63, n.6, p.564-566, 2006.
APEL, K.; HIRT, H. Reactive oxygen species: metabolism, oxidative stress, and signal transduction. Annual Review of Plant Biology, v. 55, p. 373-399, 2004.

ARAUS, J. L.; SLAFER, G. A.; ROYO, C.; SERRET, M. D. Breeding for yield potential and stress adaptation in cereals. Critical Reviews in Plant Science, v. 27, n. 6, p. 377 412, 2008

ARZANESH, M. H.; ALIKHANI, H. A.; KHAVAZI, K.; RAHIMIAN, H. A.; MIRANSARI, M. Wheat (Triticum aestivum L.) growth enhancement by Azospirillum sp. under drought stress. World Journal of Microbiology and Biotechnology, v. 27, n. 2, p. 197-205, 2011.

BALDANI, J. I.; BALDANI, V. L. D.; SELDIN, L.; DÖBEREINER, J. Characterization of Herbaspirillum seropedicae gen. nov., sp. nov., a root-associated nitrogenfixing bacterium. International Journal of Systematic and Evolutionary Microbiology, v. 36, n. 1, p. 86-93, 1986.

BALDANI, J. I.; CARUSO, L.; BALDANI, V. L. D.; GOI, S. R.; DÖBEREINER, J. Recent advances in BNF with non-legume plants. Soil Biology and Biochemistry, v. 29, n. 5, p. 911-922, 1997.

BALDANI, J. I.; BALDANI, V. L. D. History on the biological nitrogen fixation research in graminaceous plants: special emphasis on the Brazilian experience. Anais da Academia Brasileira de Ciências, v. 77, n. 3, p. 549579, 2005.

BECK, E. H.; FETTIG, S.; KNAKE, C.; HARTIG, K.; BHATTARAI, T. Specific and unspecific responses of plants to cold and drought stress. Journal of Biosciences, v. 32, n. 3, p. 501-510, 2007.

BECKERS, G. J. M.; CONRATH, U. Priming for stress resistance: from the lab to the field. Current Opinion in Plant Biology, v. 10, n. 4, p. 425-431, 2007.

BHATTACHARJEE, R. B.; SINGH, A.; MUKHOPADHYAY, S. N. Use of nitrogen-fixing bacteria as biofertiliser for non-legumes: prospects and challenges. Applied Microbiology and Biotechnology, v. 80, n. 2, p. 199-209, 2008.

BREMNER, J. M.; MULVANEY, C. S. 1982. Nitrogen total. Methods of soil analysis: Part 2, Chemical and Microbiological Properties. Soil Science Society-America, Wisconsin, 1982. 
CHAKRABORTY, U.; CHAKRABORTY, B. N.; CHAKRABORTY, A. P.; DEY, P. L. Water stress amelioration and plant growth promotion in wheat plants by osmotic stress tolerant bacteria. World Journal of Microbiology and Biotechnology, v. 29, n. 5, p. 789-803, 2013.

CHANDRA BABU, R.; ZHANG, J.; BLUM, A.; DAVID HO, T. H.; WU, R.; NGUYEN, H. T. HVA1, a LEA gene from barley confers dehydration tolerance in transgenic rice (Oryza sativa L.) via cell membrane protection. Plant Science, v. 166, n. 4, p. 855-862, 2004

COHEN,A.C.;BOTTINI,R.;PONTIN,M.;BERLI,F.J.;M ORENO,D.;BOCCALANDRO,H.;TRVAGLIA,C.N.;PI CCOLI,P.N. Arospirillum brasilense ameliorates the response of Arabidopsis thaliana to drought mainly via enhancement of ABA levels.. Physiologia Plantarum, 153:79-90, 2015.

COMPANT, S.; DUFFY, B.; NOWAK, J.; CLEMENT, C.; BARKA, E. A. Use of plant growth-promoting bacteria for biocontrol of plant diseases: principles, mechanisms of action, and future prospects. Applied and Environmental Microbiology, v. 71, n. 9, p. 4951-4959, 2005.

CONAB. Brazil's Ministry of Agriculture, Livestock and Food Supply. 2015. Acompanhamento da Safra Brasileira. Safra 2014/15, Nono Levantamento. Available from:

http://www.conab.gov.br/OlalaCMS/uploads/arquivos /15_06_11_09_00_38_boletim_graos_j Accessed in July 23, 2016.

CREUS, C. M.; SUELDO, R. J.; BARASSI, C. A. Shoot growth and water status in Aqospirillum-inoculated wheat seedlings grown under osmotic and salt stresses. Plant Physiology and Biochemistry, v. 35, p. 939-944, 1997.

CREUS, C. M.; SUELDO, R. J.; BARASSI, C. A. Water relations and yield in Arospirillum-inoculated wheat exposed to drought in the field. Canadian Journal of Botany, v. 82 , n. 2 , p. $273-281,2004$.

CRUZ, C.D. Genes: a software package for analysis in experimental statistics and quantitative genetics. Acta Scientiarum Agronomy, v. 35, n. 3, p. 271-276, 2013.

DIMKPA, C.; WEINAND, T.; ASCH, F. Plantrhizobacteria interactions alleviate abiotic stress conditions. Plant, Cell \& Environment, v. 32, n. 12, p. 1682-1694, 2009.
DOORNBOS, R. F.; LOON VAN, L. C.; BAKKER, P. A. H. M. Impact of root exudates and plant defense signaling on bacterial communities in the rhizosphere - a review. Agronomy for Sustainable Development, v. 32, n. 1, p. 227-243, 2012.

FARINA, R.; BENEDUZIA, A.; AMBROSINI, A.; CAMPOS, S. B.; LISBOA, B. B.; WENDISCH, V.; VARGAS, L. K.; PASSAGLIA, L. M. P. Diversity of plant growth-promoting rhizobacteria communities associated with the stages of canola growth. Applied Soil Ecology, v. 55, p. 44-52, 2012.

FAO. 2017.Food and Agricultural Organization of the United Nations. Cereal supply and demand brief. Capturated in $04 / 24 / 2017$ from http://www.fao.org/worldfoodsituation/csdb/en/

FAROOQ, M.; WAHID, A.; KOBAYASHI, N.; FUJETA, D.; BASRA, S. M. A. Plant drought stress: effects, mechanisms and management. Agronomy Sustainable Development, 29, 185-212, 2009.

GODINHO, C. H. W. 2013. Rural Agronomy Department, Ministry of Agriculture and Food Supply of Parana State. Trigo - Análise da Conjuntura Agropecuária in Safra 2012-2013. Available from: http://www.agricultura.pr.gov.br/arquivos/File/deral/P rognosticos/Trigo_2013.pdf Accessed in July 23, 2016.

GOMES, A.A.; REIS, V.M.; BALDANI, V. L.; GOI, S.R.. Relação entre distribuição de nitrogênio e colonização por bactérias diazotróficas em cana-deaçúcar. Pesquisa Agropecuária Brasileira, v.40, n.11, p.1105$1113,2005$.

HAMDIA, M. A. S.; SHADDAD, M. A. K.; DOAA, M. M. Mechanisms of salt tolerance and interactive effects of Arospirillum brasilense inoculation on maize cultivars grown under salt stress conditions. Plant Growth Regulation, v. 44, n. 2, p. 165-174, 2004.

HAYAT, R.; ALI, S.; AMARA, U.; KHALID, R.; AHMED, I. Soil beneficial bacteria and their role in plant growth promotion - a review. Annals of Microbiology, v. 60, n. 4 , p. $579-598,2010$.

JONES, H. D. Wheat transformation: current technology and applications to grain development and composition. Journal of Cereal Science, v. 41, n. 2, p. $137-$ 147, 2005. 
JUHNKE, M. E.; MATHRE, D. E.; SANDS, D. C. Relationship between bacterial seed inoculum density and rhizosphere colonization of spring wheat. Soil Biology and Biochemistry, v. 21, n. 4, p. 591-595, 1989.

KASIM, W. A.; OSMAN, M. E.; OMAR, M. N.; ELDAIM, I. A.; BEJAI, S.; MEIJER, J. Control of drought stress in wheat using plant-growth-promoting bacteria. Journal of Plant Growth Regulation, v. 32, n. 1, p. 122-130, 2013.

KHAN, S. U.; DIN, J. U.; QAYYUM, A.; JAN, N. E.; JENKS, M. A. Heat tolerance indicators in Pakistani wheat (Triticum aestivum L.) genotypes. Acta Botanica Croatica, v. 74, n. 1, p. 109-121, 2015.

LEMOS, J. M.; VENDRUSCOLO, E. C. G.; SCHUSTER, I.; SANTOS, M. F. Physiological and biochemical responses of wheat subjected to water deficit stress at different phenological stages of development. Journal of Agricultural Science and Technology, v. 1, p. 22-30, 2011.

LIU, C.; LIU, Y.;GUO, K.; DAYONG FAN D.; LI, G.; ZHENG, Y.;YU, L.;YANG, R. Effect of drought on pigments, osmotic adjustments and antioxidant enzymes in six woody plant species in karst habitats of south western China. Environment Experimental Botany 71:174183,2011 .

MARCHIORO, V. S.; FRANCO, F. A.; NORA, T. D.; OLIVEIRA, E. F.; SCHUSTER, I.; EVANGELISTA, A.; ROCHA, L.; POLO, M. CD 120 wheat cultivar, standard quality soft, for the Southern Region of Brazil. Crop Breeding and Applied Biotechnology, v. 11, n. 4, p. 375378, 2011.

MASWADA, H. F.; EL-KADER, N. I. K. Redox halopriming: a promising strategy for inducing salt tolerance in bread wheat. Journal of Agronomy and Crop Science, v. 202, n. 1, p. 37-50, 2016.

MEENA, K. K., SORTY, A. M., BITLA, U. M., CHOUDHARY, K., GUPTA, P., PAREEK, A., MINHAS, P. S. Abiotic Stress Responses and MicrobeMediated Mitigation in Plants: The Omics Strategies. Frontiers in Plant Science, v.8, n.172, p 1-25. 2017

NAIMAN, A. D.; LATRÔNICO, A.; SALAMONE, I. E. G. Inoculation of wheat with Azospirillum brasilense and Pseudomonas fluorescens: Impact on the production and culturable rhizosphere microflora. European Journal of Soil Biology, v. 45, n. 1, p. 44-51, 2009.

NEIVERTH, A.; DELAI, S.; GARCIA, D. M.; SAATKAMP, K.; SOUZA, E. M.; PEDROSA, F. O.; GUIMARÃES, V. F.; SANTOS, M. F.; VENDRUSCOLO, E. C. G.; COSTA, A. C. T. Performance of different wheat genotypes inoculated with the plant growth promoting bacterium Herbaspirillum seropedicae. European Journal of Soil Biology, v. 64, p. 1-5, 2014.

OKUYAMA, L. A.; FEDERIZZI, L. C.; BARBOSA NETO, J. F. Correlation and path analysis of yield and its components and plant traits in wheat. Ciência Rural, v. 34, n. 6, p. 1701-1708, 2004.

ROESCH, L. F. W.; OLIVARES, F. L.; PASSAGLIA, L. M. P.; SELBACH, P. A.; SÁ, E. L. S.; CAMARGO, F. A. O. Characterization of diazotrophic bacteria associated with maize: effect of plant genotype, ontogeny and nitrogen-supply. World Journal of Microbiology and Biotechnology, v. 22, n. 9, p. 967-974, 2006.

ROJAS-TAPIAS, D.; MORENO-GALVÁN, A.; PARDO-DÍAZ, S.; OBANDO, M.; RIVERA, S.; BONILLA, R. Effect of inoculation with plant growthpromoting bacteria (PGPB) on amelioration of saline stress in maize (Zea mays). Applied Soil Ecology, v. 61, p. 264-272, 2012

SANTOS, L. T.; PINTO, R. J. B.; FRANCO, F. A.; SCHUSTER, I. Inheritance and potential use of grain color in the Inheritance and potential of genotypes resistant to pre-harvest to pre-harvest sprouting in wheat. Crop Breeding and Applied Biotechnology, v. 10, n. 3 p. 218 224, 2010

SCHONFELD, M. A.; JOHNSON, R. C.; CARVER, B. F.; MORNHINWEG, D. W. Water relations in winter wheat as drought resistance indicators. Crop Science, v. 28, n. 3, p. 526-531, 1988.

SENGUPTA, A.; GUNRI, S. K. Microbial intervention in agriculture: An overview. African Journal of Microbiology Research, v. 9, n. 18, p. 1215-1226, 2015.

SPAEPEN, S.; DOBBELAERE, S.; CROONENBORGHS, A.; VANDERLEYDEN, J. Effects of Azospirillum brasilense indole-3-acetic acid production on inoculated wheat plants. Plant and Soil, v. 312, n. 1-2, p. 15-23, 2008. 
TARRAND, J. J.; KRIEG, N. R.; DÖBEREINER, J. A taxonomic study of the Spirillum lipoferum group, with descriptions of a new genus, Azospirillum gen. nov. and two species, Azospirillum lipoferum (Beijerinck) comb. nov. and Azospirillum brasilense sp. nov. Canadian Journal of Microbiology, v. 24, n. 8, p. 967-980, 1978.

VARGAS, L.; CARVALHO, T. L. G.; FERREIRA, P. C. G.; BALDANI, V. L. D.; BALDANI, J. I.; HEMERLY, A. S. Early responses of rice (Oryza sativa) seedlings to inoculation with beneficial diazotrophic bacteria are dependent on plant and bacterial genotypes. Plant and Soil, v. 356, n. 1-2, p. 127-137, 2012.

VENDRUSCOLO, ECG.; SCHUSTER, I.;SERRA NEGRA,E.;SCAPIM C.A. Callus induction and plant regeneration by Brazilian new elite wheat genotypes. Crop Breeding and Applied Biotechnology v.8: p.195-201, 2008.

ZADOKS, C. J.; CHANG, T. T.; KONZAK, F. C. A decimal code for the growth stages of cereals. Weed Research, v. 14, n. 6, p. 415-421, 1974. 